\title{
Thoughts And Actions In Promoting Equality That Include Considerations From Work With The United Nations Association Of Japan
}

Lawrence Karn, Otsuma Women's University, Japan

Takahiko Hattori, Otsuma Women's University, Japan

\begin{abstract}
This paper explores a number of classical and contemporary thinkers and advances the thesis that the touchstone for social justice may be expressed in two words, "trade places," and that this exhortation must be applied internationally. In such cases, its application may sometimes be possible and useful as a practical thought experiment. The "trade places" notion is a plan of action, which may be termed the "responsibility of knowledge."
\end{abstract}

Keywords: Social Justice; International Relations; United Nations; Universal Declaration of Human Rights; United Nations Association of Japan; United Nations Association of Japan Test of English; International Red Cross

\section{INTRODUCTION}

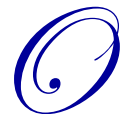

ur particular area of interest is in how knowledge of world news and international events challenges us to develop a more internationalist perspective. A working definition of internationalism includes the motivation to diminish inequalities between people in richer and poorer countries. Necessarily included in any meaningful diminution of inequalities must be the need to diminish inequalities based on race, religion, gender, sexual orientation and other such arbitrary criteria. Basic needs, such as food, shelter, medical care, safety and economic security must also be part of the movement towards equality. Questions of respect and identity, of how and why others may be represented in advocating on their behalf or in attempting to understand their situation, are also relevant to the quest for equality.

An earlier work critiqued Rawl's ${ }^{1}$ notion of justice as fairness, focusing particularly on the "veil of ignorance" ${ }^{2}$ trope, advanced the need for justice as equality. An additional work examined the question of essentialism in four feminist thinkers. There the focus was on the degree to which inequalities might be termed essential or innate versus the degree to which inequalities may be considered situational or nurtured.

This paper continues the exploration of how seeking justice based on equality may accommodate more nuanced formulations, including notions of integrity, respect and identity.

Additionally, and as a practical action, the "trade places" exhortation will be advanced and explored as an element of praxis for actual rather than purely theoretical implementation. The aim throughout this paper is to present an always discursive and occasionally anecdotal narrative to support this thesis. Drawing on thinkers and concepts that have been explored in surveying a representative sample of the works, philosophies, and the

\footnotetext{
${ }^{1}$ Rawls, J. (1999). A theory of justice. Harvard University Press. Rawls, J. Justice as fairness: Political not metaphysical. Retrieved from http://www.jstor.org.proxy.myunion.edu/action/doBasicSearch?Query=Rawls+\%22Justice+as+Fairness\%22\&Search=Search\&gw=jtx\&prq=Raw $1 \mathrm{~s}+\% 22 \mathrm{Justice}+\mathrm{as}+$ Fairness $\% 22 \& \mathrm{hp}=25 \& \mathrm{acc}=\mathrm{off} \&$ aori $=$ off $\& \mathrm{wc}=$ on $\& \mathrm{fc}=$ off

${ }^{2}$ Rawls, J. "Justice as Fairness: Political not Metaphysical" on page 223.
} 
foundational themes on social justice, this paper will advance a thesis that includes practical examples and seeks to allow the illustrative interplay of theory and praxis.

\section{METHOD - OPENING ASSERTION}

This paper will advance the thesis that the simple test of the justness of any system of justice-the touchstone for social justice - may be expressed in two words and envisioned in a single sentence. The words are, "trade places" and the sentence is the challenge, "If you imagine your system is just, please trade places with the most disadvantaged individual at the very lowest level of your system and ask yourself how you would feel." This exhortation must also be applied internationally, although in such cases its application is often more in the nature of a practical thought experiment.

That directive may sound like a variation of John Rawls" ${ }^{3}$ trope of the "veil of ignorance", which has been explored in an earlier paper on this subject. Rather, the "trade places" notion is a plan of action based on the opposite of the "veil of ignorance" and which may be termed the "responsibility of knowledge."

\section{Area of Discussion}

Trading places also links to feminist thinkers ${ }^{4}$ and the quest for an irreducible essence of individuality, Fanon $^{5}$ and writers on the question of identity and "otherness" and how this gap can be meaningfully bridged and also considers the questions of "who speaks for whom" and how "others" may be represented.

The course this paper charts will be chronological and interconnected with ideas engaged with in a survey of themes in social justice. Illustrative anecdotes may be semi-autobiographical and drawn from actual and personal real-life events rather than purely conjectural "thought experiment" ${ }^{\prime \prime}$ tropes. This is done in deferential recollection of Joan W. Scott ${ }^{7}$ and Bell Hooks, ${ }^{8}$ insightful cautionary tales. Scott and Hooks provide object lessons in being aware of when one's assumptions are based on or borne out by the evidence of experience and when there is a need for caution and forbearance in concluding one's uniquely situated observations, whether from a position of privilege or prejudice (which often amount to the same thing), may generalize into a blueprint for the emancipation of society and the rectification of systemic injustices. The underlying question is in how one may be a benefit to the community, be an asset to the collective, what makes life worth living? As Nussbaum ${ }^{9}$ and Foucault ${ }^{10}$ explore: How may we define what it means to be human and how does confronting oneself in juxtaposition to others aid one in telling the truth about oneself?

At the onset, brief comment is needed on the narrative method this paper will employ to illustrate its points. To sustain the thesis that trading places and its concomitant theoretical constructs-seeing one's self from the position of the "other" and recognizing one's identity from the hermeneutic of a position of economic, social, and capability equality - is not only viable but necessary, a few examples may be usefully sketched out. These are derived from personal experiences in the context of co-op involvement in Toronto, ashram life in Nassau, Bahamas and work as a United Nations Association of Japan Test of English writer and chief examiner based in Tokyo and who has also served in other locations in the region.

\footnotetext{
${ }^{3}$ Ibid, page 235 .

${ }^{4}$ Baier, A. The need for more than justice. In Held (ed.), Justice and care (pp. 47-58). Gilligan, C. (1995). Moral Orientation and Moral Development. In V. Held (ed.), Justice and care: Essential readings in feminist ethics (pp. 31-46). Boulder, CO: Westview Press. Irigaray, L. (1995). The question of the other. Yale French Studies, 87, 7-19. Tronto, J. Women and caring: What can feminists learn about morality from caring? In Held (ed.), Justice and care (pp. 101-115).

${ }^{5}$ Fanon, F. (1952). The facts of blackness. (L'expérience vécu d'un Noir). Chapter 5 of Black Skin, White Masks. Grove Press, 1967. Retrieved from http://www.nathanielturner.com/factofblackness.htm on page 8 .

${ }^{6}$ Rawls problematic "thought experiment" tropes include his formulation of the original position, the veil of ignorance and state of reflective equilibrium. In Rawls' system, the thinking/deliberating that individuals do behind the veil of ignorance is done in the original position, which may only be accessed in a state of reflective equilibrium. Rawls, J. "Justice as Fairness: Political not Metaphysical" on page 228.

${ }^{7}$ Scott, J. (1991, Summer). The evidence of experience. Critical Inquiry, 17(4), 773-797.

${ }^{8}$ Hooks, B. (1993, Spring). A revolution of values: The promise of multi-cultural change. Journal of the Midwest Modern Language Association, $26(1)$.

${ }^{9}$ Nussbaum, M. (1992, May). Human functioning and social justice: In defense of Aristotelian essentialism. Political Theory, 20(2), $202-246$.

${ }^{10}$ Foucault. Retrieved from http://www.foucault.info/documents/foucault.technologiesofself.en.html
} 
The rationale for such personal accounts is that they may contribute something new to the discussion on this topic to illustrate the praxis of trading places or having to take the place of the other, with narrative experiences that may not be unique individually, but may form a unique collection that brings concepts to life.

\section{DISCUSSION}

\section{Co-op Involvement in Toronto}

The first set of "trading places" experiences is linked to justice and virtue as community obligation. It may also be classed under the heading of communitarian and inter-subjective approaches. These relate to involvement with the cooperative movement in Toronto. Specifically, issues related to basic requirements of life - money, food and shelter-will be discussed.

The Bread and Roses credit union in Toronto was a manifestation of the wider movement, ranging from farm cooperatives to micro-financing in developing [by Western standards linked to economic prosperity] nations, to provide a structure for cooperative endeavor aimed at providing financial security and equality. A brief overview of social justice issues Bread and Roses concerned itself with is noted below. ${ }^{11}$ The principle writer's involvement with Bread and Roses, beyond personal membership, was in setting up a member-acquisition cross-promotion with a high-profile (aka headline grabbing) conservation advocacy group in my role as Program Director for the Temagami Wilderness Fund.

Karma Food Co-op" ${ }^{12}$ characterizes what might be classed as a micro-community in the iteration of "trading places" as a particular instance of justice and virtue as community obligation. Joining this cooperative, as a working member, meant that any task - from sweeping floors to stocking shelves to ordering goods - would be required on a rotating basis for the benefit of the enterprise. This willingness to trade places was a condition of membership.

Toronto's Windward Co-op ${ }^{13}$ is one of the 51 housing cooperatives in that city. It is also one of the 895 housing cooperatives in Canada ${ }^{14}$ that meet the member-run, non-profit status. At Windward, active participation was a condition for membership in a living environment which was 40 percent occupied by individuals with physical disabilities that rendered them wheelchair reliant and 100 percent wheelchair accessible. During the principle writer's five years on the Board of Directors and two as president, it was clear that issues of housingincluding job and income losses by members, appeals to the emergency housing fund-required the understanding that each had an equal stake in the well being of our community.

The three examples above, in which trading places engenders justice and virtue as community obligation, also present the interesting condition that trading places or being required to adopt the position of the other in the pursuit of a wider social good, was "mandatory by choice" and members had the option of withdrawing. Joining up was always based on a membership committee interview and goals, values and outcomes that were clearly laid out and yet open to debate.

\footnotetext{
${ }^{11}$ Bread and Roses is described at http://www.connexions.org/CxLibrary/CX2153.htm Abstract: Bread and Roses calls itself a financial cooperative for social change. It makes loans to individuals and groups engaged in alternate economic or social endeavors which aim for a more just and democratic society. This issue of the newsletter begins with a description of the most recent membership meeting when a loan interest refund from 1979 earnings was approved. The meeting also engaged in a lengthy but unresolved debate about whether the credit union should operate by consensus or by majority vote. The issue of whether Bread and Roses should loan money to "progressive" political candidates was also argued. In his column, the manager argues that the credit union should clarify its position on a number of philosophical and practical points if Bread and Roses is to meet the challenge of an increasingly polarized society. More and more alternate organizations, facing financial pressures, appear to want to break out of their past isolation by creating new opportunities for financial cooperation. The newsletter also presents the pros and cons of offering RRSP's - Bread and Roses is currently considering this question - "Are these a healthy way for individual saving, avoiding paying for government profligacy and strengthening the credit union or (are they) a hopelessly class-ridden dodge which ultimately shifts the tax burden even more to the poor who cannot save?" The author of one article comments that such debates within the membership indicate that Bread and Roses is aware that its own practice must be consistent with its goals and the goals of its constituency in promoting social change, all the while trying to operate responsibly within a financial system that inhibits social change.

${ }^{12} \mathrm{http}: / /$ www.karmacoop.org/

${ }_{13}^{13} \mathrm{http}: / /$ windwardcoop.ca/

${ }^{14}$ http://www.chfcanada.coop/eng/pages2007/home.asp
} 


\section{Ashram Life in Nassau, Bahamas}

The next iteration of the trading places touchstone of social justice comes from a six-month engagement as unofficial staff at a yoga ashram ${ }^{15}$ in the Bahamas. All guests and particularly yoga teacher training course students and quasi-staff were required to do "karma yoga" to maintain the ashram. The "karmic" (and what may be characterized as a trading places activity) nature of the activity was assigned by swamis who, after meditation on the type of change in status or position that would provide the greatest karmic benefit to the "practicant," assigned roles and duties that ranged from working in the gift shop (for individuals such as writers, whose ordinary lives involved solitary activities) to perceived dirty jobs (such as cleaning toilets and bathrooms) for New York fashion models whom the swamis perceived as flaunting a sensuous yoga chic (and who humorously complained they had been criticized for being "yoga chicks").

As quasi-staff, one traded places doing all tasks - reservations, accounting, construction, boat captaining, kitchen staff, dishwashing, maintenance, etc. - that were required. One even traded places with the rats, though not with the rats' consent. The garbage shed had a concrete floor, but wooden walls that were no match for rodent persistence. Opening the doors to be greeted by banqueting rats meant needing to smack the floor with a shovel to set the critters scampering away and scaring them off with imprecations like, "You've had your chance; now it's my turn to rummage in the trash."

Turning to the worst off in our world, in reflection on the rats' lot in life, we may ponder, "What if the only food available to me was from searching through garbage to find whatever scraps might sustain my life?" Shockingly, that is the case for many individuals in the most dangerously war-torn and in hospitable regions of our planet.

\section{Work with the United Nations Association of Japan}

Daily, we learn of extreme inequalities and may be numbed by the magnitude of suffering and injustice in the world. How may the notion of trading places exist in any reasonable iteration in this context? Here, this paper will adduce a third anecdote relating to how the notion of trading places may bring heightened sensitivity and greater understanding which may, in turn, increase the chances of an internationalist perspective being enhanced and advanced toward redressing global inequalities.

We may agree at the onset that simply because we don't live in an egalitarian paradise doesn't mean it's irrelevant to engage in tangible acts to create greater equality. United Nations' goals ${ }^{16}$ may be used as a clear reference, in ideal terms, that serves as a template for equality.

As a prelude to discussing our work with the United Nations Association of Japan ${ }^{17}$, a few general remarks will relate the goals of the United Nations with some of the writers cited in this paper. As these writers have been critiqued by us in depth elsewhere, they will be mentioned here quite briefly. With reference to the United Nations Universal Declaration of Human Rights ${ }^{18}$ in particular, three or four specific declarations are relevant.

Article 12, which declares the right to freedom from attacks on "honor and reputation,"19 speaks to Axel Honneth's Integrity and Disrespect. ${ }^{20}$ This satisfies the second and third condition of Honneth's observation that "three patterns of recognition-love, rights, and solidarity - set down the formal requirements for conditions of interaction within which human beings can feel assured of their "dignity" or "integrity.",21

\footnotetext{
${ }^{15} \mathrm{http}: / /$ www.sivanandabahamas.org/

${ }^{16}$ Today's Guide to the United Nations. (2007). Tokyo, Japan: Sanshusha Publishing. On page 174 under "Purposes and Principles," page 237 in the "Universal Declaration of Human Rights."

${ }^{17}$ The United Nations Association of Japan is available at http://www.unaj.or.jp/ (Japanese site) and

http://www.unaj.or.jp/zaidanhoujin/jigyou_e.html provides some information about the organization in English.

${ }_{18}^{18}$ Today's Guide to the United Nations, Universal Declaration of Human Rights, page 237.

${ }^{19}$ Ibid.

${ }^{20}$ Honneth, A. Integrity and disrespect: Principles of a conception of morality based on the theory of recognition. Retrieved from http://www.jstor.org/discover/10.2307/192001 ?uid=3738328\&uid=2\&uid=4\&sid=21102703385497

${ }^{21}$ Honneth, A. Integrity and disrespect: Principles of a conception of morality based on the theory of recognition. (p. 195). Retrieved from http://www.jstor.org/discover/10.2307/192001 ?uid=3738328\&uid=2\&uid=4\&sid=21102703385497
} 
Article 15 , which enshrines rights concerning national identity, ${ }^{22}$ speaks to concerns so viscerally expressed in Franz Fanon's Facts of Blackness as the quest for identity in a context where race and the fact of blackness are used as markers that are as suffocating as they are inescapable. ${ }^{23}$

Articles 18 and 19 respectively, ${ }^{24}$ which declare rights concerning freedom of thought, conscience and religion and rights concerning freedom to express opinions for oneself, speak to issues raised by Beatrice Hanssen in The Ethics of the Other ${ }^{25}$ and Chantal Mouffe in Which Ethics for Democracy? ${ }^{26}$ Hanssen would surely have appreciated the significance of these declarations in the light of the struggle for recognition. ${ }^{27}$ For Mouffe, the freedom to think freely and express such opinions on one's own behalf are central to the "agonistic confrontation"28 that is so necessary for the prosperity of democracies.

Now, using the principle writer's work with the United Nations Association of Japan Test of English in the role of chief examiner, one example of changing places - as more of an in-practice thought experiment than an actual possibility - will be given from the personal interview portion of the highest-level exam. This is an oral exam designed to test language proficiency, knowledge of the United Nations, current news events, and the ability to suggest diplomatic resolutions to vexing international issues.

In reformulating some of the practices in this exam for assessing candidates, one instructed candidates to psychologically trade places with disadvantaged individuals they may encounter globally. Further, one may also fashion a conflicting loyalties condition for candidates. For instance, requesting candidates to imagine that they are in roles that are opposed to their own position creates reversals. While the actual interview content is confidential, the following is an example of what a usual reversal would entail. A candidate may be a navy captain who has the responsibility of enforcing anti-piracy activities off the Somali coast. The request would be, "Please take a moment and imagine you are a Somali pirate; then please make this panel understand why you are engaged in these activities."

These three varied experiences-with communitarian co-ops, karma yoga as an equalizing force, the United Nations screening exam ${ }^{29}$ as a role-reversal thought experiment venue-provide a basis for discussing the thesis that trading places in as real and actual a way as possible allows for the emergence of collective and individual insights into the need for equality.

In the last third of this paper, we may touch on a number of additional instances where changing places engenders movement toward diminishing inequalities. We will also consider the damaging effects of structural inequalities on the ameliorating potential of trading places or being assigned to a situation of arbitrary role reversal.

First, we may consider instances where changing places engenders movement toward diminishing inequalities. For example, effectively trading places with imperiled others may involve going to a foreign country to "witness" the conditions severely disadvantaged people are forced to endure. ${ }^{30}$ This is also the function of United Nations' observer missions ${ }^{31}$ and other NGO advocacy groups such as Amnesty International ${ }^{32}$ and Greenpeace, ${ }^{33}$ which seek to improve a range of conditions worldwide.

${ }^{22}$ Today's Guide to the United Nations, Universal Declaration of Human Rights, page 237.

${ }^{23}$ Fanon, F. (1952). The facts of blackness. (L'expérience vécu d'un Noir). Chapter 5 of Black Skin, White Masks. Grove Press, 1967. (p. 8).

Retrieved from http://www.nathanielturner.com/factofblackness.htm

${ }^{24}$ Today's Guide to the United Nations, Universal Declaration of Human Rights, page 237.

${ }^{25}$ Hanssen, B. (2000). The ethics of the other. In M. Garber, B. Hanssen, \& R. L. Walkowitz, The turn to ethics. Ed. (Chapter 8). New York and London: Routledge

${ }^{26}$ Mouffe, C. (2000). Which ethics for democracy? In M. Garber, B. Hanssen, \& R. L. Walkowitz, The turn to ethics. Ed. (Chapter 6). New York and London: Routledge.

${ }_{28}^{27}$ Hanssen, op cit., page 137.

${ }^{28}$ Mouffe, op cit., page 92.

${ }^{29}$ The United Nations site, which lists exams that test English ability, is available at http://www.un.org/exam/lpe/welcome/main.asp

${ }^{30} \mathrm{http} / / /$ en.wikipedia.org/wiki/Global_Witness

${ }^{31} \mathrm{http}: / /$ en.wikipedia.org/wiki/List_of_United_Nations_peacekeeping_missions\#Current_deployment_.2816.29

${ }^{32} \mathrm{http}: / /$ www.amnesty.org/

${ }^{33} \mathrm{http} / / / \mathrm{www}$.greenpeace.org/international/en/ 


\section{ADDITIONAL DISCUSSION}

Taking on the role of another to experience the fact of blackness, journalist John Howard Griffin's nonfiction work Black Like Me, famously chronicled Griffin's travels through Louisiana, Mississippi, Alabama, and Georgia in 1959 as a white man who had transformed himself into a black man in an extremely influential instance of trading places. ${ }^{34}$

Further exploring how taking the role of the other broadens understanding and engenders attitude shift, the Stanford University prison experiment ${ }^{35}$ where one university class was arbitrarily divided into prisoners and guards, explored how behaviors and attitudes changed based on the roles people played even when they knew they were role-playing.

Jane Elliot's brown eyed/blue eyed experiment ${ }^{36}$ devised to explore prejudice and racism all too quickly demonstrated how giving an arbitrarily chosen group a real advantage quickly motivated behavior that (as in the case of the Stanford University prison experiment) changed attitude to justify inequality.

Both the Stanford prison and the Elliot brown-eyed/blue-eyed experiments demonstrated a negative attitude shift because one group was given rewards at the expense of the other group based on a system of structural inequality. This lends support to the assertion that race, religion, color, citizenship, and other arbitrary features that may be chosen have all been not so much differences as excuses or justifications for inequality.

Moving from the discussion of rewards for structural inequality to the genesis of current conditions exemplifying structural inequality, New York Times op-ed wrier Joseph E. Stiglitz has commented in Inequality Is a Choice $^{37}$ on the arbitrary nature of structural inequalities.

Based on research by World Bank economist Branko Milanovic, Stiglitz documents that "It is not true that inequality is an inevitable byproduct of globalization, the free movement of labor, capital, goods and services, and technological change that favors better-skilled and better-educated employees. ${ }^{38}$ Stiglitz suggests that political will is the governing force in creating and maintaining structural inequalities.

While Mouffe may claim dissent and agonistic differences preserve democracies ${ }^{39}$ Stiglitz contends that inequalities [which are surely the subject of dissent and agonistic differences] most certainly do not enhance democracy and notes, "American inequality began its upswing 30 years ago, along with tax decreases for the rich and the easing of regulations on the financial sector. That's no coincidence. It has worsened as we have underinvested in our infrastructure, education and health care systems, and social safety nets. Rising inequality reinforces itself by corroding our political system and our democratic governance." ${ }^{\prime 0}$

A scathing indictment of the inability to even imagine trading places - the condition where the lives of others sharing the same society are almost unfathomable - is presented in a passage from the concluding paragraph

\footnotetext{
${ }^{34}$ Griffin, J. H. (1962). Black Like Me. New York: Collins Publishing.

${ }^{35} \mathrm{http} / / / \mathrm{hrsbstaff}$. ednet.ns.ca/devrob/Sociology\%2012/pavlov.htm

${ }^{36}$ Ibid.

${ }^{37}$ Stiglitz, J. E. (2013, October 13). Inequality Is a Choice. New York Times. Retrieved from http://opinionator.blogs.nytimes.com/2013/ 10/13/inequality-is-a-choice/?_r=0 states that the real and palpable danger internationally is: "To this day, inequality between countries is far greater than inequality within countries." "Of the advanced economies, America has some of the worst disparities in incomes and opportunities, with devastating macroeconomic consequences. The gross domestic product of the United States has more than quadrupled in the last 40 years and nearly doubled in the last 25 , but as is now well known, the benefits have gone to the top - and increasingly to the very, very top." The next paragraph details the statistics in historical context, from the perspective of mid-October 2013, noting that "Last year, the top 1 percent of Americans took home 22 percent of the nation's income; the top 0.1 percent, 11 percent. Ninety-five percent of all income gains since 2009 have gone to the top 1 percent. Recently released census figures show that median income in America hasn't budged in almost a quarter-century. The typical American man makes less than he did 45 years ago (after adjusting for inflation); men who graduated from high school but don't have four-year college degrees make almost 40 percent less than they did four decades ago."

${ }^{38}$ Ibid.

${ }^{39}$ Mouffe, C. (2000). Which Ethics for Democracy? In M. Garber, B. Hanssen, \& R. L. Walkowitz, The Turn to Ethics. Ed. (Chapter 6, p. 92). New York and London: Routledge.

${ }^{40}$ Stiglitz, op cit.
} 
of Stiglitz's article, in which he notes, "Some countries will be successful in creating shared prosperity - the only kind of prosperity that I believe is truly sustainable. Others will let inequality run amok. In these divided societies, the rich will hunker in gated communities, almost completely separated from the poor, whose lives will be almost unfathomable to them, and vice versa." 41

A slightly abstracted rendering of the trading places suggestion is in the form of the International Red Cross urging action video game makers to factor the rules of military engagement into the gaming/virtual world ${ }^{42}$ so that the deaths of civilians and acts of extreme brutality and other actions that might properly be classed as war crimes will prevent the "offenders" and "criminals" from winning the game. ${ }^{43}$ It may be argued that imposing such consequences compels players to, while not actually switching places, consider the situation of the innocent while the gamers are acting rather than simply as a consequence of the gamers' actions. This is an especially important distinction in light of the fact that studies of players of these games indicate, "many of those young men are in the military themselves" 44 and that "anything which reminds them of the difference between legitimate battle and a war crime is, the Red Cross believes, worthwhile." 45

\section{CONCLUSION}

Moving toward the conclusion of this paper, a number of observations may be made on the usefulness of actual attempts to trade places in order to reach a deeper understanding and commitment on issues of social justice and the need for greater equality - the responsibility of knowledge concept.

While the theme that we must trade places with the most disadvantaged individual or group in a system to assess the justness of that system may be disparaged as a simple "golden rule" to treat others as you would like to be treated homily, it is also a useful theme to follow in exploring the responsibility of knowledge concept. Appreciating the need for enlightenment, ${ }^{46}$ for just institutions, ${ }^{47}$ for engagement with and resolution of gender disparity issues ${ }^{48}$ for ensuring that all individuals enjoy the right to respect and dignity, ${ }^{49}$ for the need to safeguard the rights individuals and groups have to establish their own identity, ${ }^{50}$ and that they are fairly and sufficiently represented and able to tell their own story in their own words ${ }^{51}$ are all evoked by the responsibility of knowledge concept.

\footnotetext{
${ }^{41}$ Ibid.

${ }^{42}$ BBC World News. Should the rules of war be included in computer games? Retrieved from http://www.bbc.co.uk/news/technology-24318061 Francois Senechaud of the International Committee of the Red Cross, in interview, comments that video games of warfare are "very close to reality" and "it's very difficult make the difference [sic] between any real footage and the footage that you can get from video games."

${ }^{43}$ Text at BBC World News at http://www.bbc.co.uk/news/technology-24318061 notes that, "The Red Cross wants to have a greater influence in the virtual world of battlefields. The aid organization is arguing that as virtual war games are becoming close to reality, the rules of war should be included. It claims games such as Medal of Honour, or Call of Duty should make sure that actions which could be war crimes are not rewarded with victory in a virtual battle." The video coverage at approximately the 1 minute 15 second point notes "attacks on civilians and even torture during interrogation are allowed" and continues at approximately the 1 minute 30 second point that "...one manufacturer, with the help of the Red Cross, has factored in a new element. Break the laws of war and you lose the game."

${ }^{44}$ The video coverage at approximately the 2 minute 10 second point notes "...and many of those young men are in the military themselves. Anything which reminds them of the difference between legitimate battle and a war crime is, the Red Cross believes, worthwhile." http://www.bbc.co.uk/news/technology-24318061

${ }^{45}$ Ibid.

${ }^{46}$ Kant, E. (1974). What is Enlightment? Available at english.ncu.edu.tw/stewart/Teaching/.../What\%20is\%20Enlightenment.pdf

${ }^{47}$ Rawls, J. (1999). A theory of justice. Harvard University Press. Rawls, J. Justice as fairness: Political not metaphysical. Retrieved from http://www.jstor.org.proxy.myunion.edu/action/doBasicSearch?Query=Rawls+\%22Justice+as+Fairness\%22\&Search=Search\&gw=jtx\&prq=Raw $1 \mathrm{~s}+\% 22 \mathrm{Justice}+\mathrm{as}+\mathrm{Fairness} \% 22 \& \mathrm{hp}=25 \& \mathrm{acc}=\mathrm{off} \&$ aori $=$ off $\& \mathrm{wc}=$ on $\& \mathrm{fc}=$ off

${ }^{48}$ Gilligan, C. (1995). Moral orientation and moral development. In V. Held (ed.), Justice and care: Essential readings in feminist ethics (pp. 3146). Boulder, CO: Westview Press. Baier, A. The need for more than justice. In Held (ed.), Justice and care (pp. 47-58). Tronto, J. Women and Caring: What can Feminists Learn About Morality from Caring? In Held (ed.). Justice and Care (pp. 101-115). Irigaray, L. (1995). The question of the other. Yale French Studies, 87, 7-19. JSTOR.

${ }^{49}$ Honneth, A. (1992, May). Integrity and disrespect: Principles of a conception of morality based on the theory of recognition. Political Theory, 20(2), 187-201.

${ }^{50}$ Bhabha, H. (2000). On cultural choice. In M. Garber, B. Hanssen, \& R. L. Walkowitz (eds.), The turn to ethics (Chapter 9). New York and London: Routledge. and Fanon, F. (1967). The facts of blackness. (L'expérience vécu d'un Noir) Chapter 5 of Black Skin, White Masks. Grove Press.

${ }^{51}$ Mouffe, C. Which ethics for democracy? In B. Hanssen, The Turn to Ethics (Chapter 6). "The Ethics of the Other." In The turn to ethics (Chapter 8).
}

Copyright by author(s); CC-BY 
The invocation to trade places in as actual and real a fashion as possible, whether by effectively trading places with imperiled others by going to a foreign country to "witness" the conditions severely disadvantaged people are forced to endure, through United Nations' observer missions and other good works in both education and active participation, through NGO advocacy groups such as Amnesty International and Greenpeace or by a thought experiment in a practical and real-life setting, is a logical extension of the responsibility of knowledge concept and must always be a test for justness and call for greater equality and urgent diminution of momentous hardships and grave injustices that are inflicted on too many of the world's people.

\section{RATIONALE FOR THIS PAPER}

This paper was written in the main by Lawrence Karn, with the very kind assistance and support of Takahiko Hattori. The narrative of this paper also draws from Lawrence Karn's personal experiences as the Vicechairperson of the Advisory Committee for the United Nations Association's Test of English (UNATE) actively serving as a writer for the paper portion and as chief examiner for the interview portion of the UNATE exam. In this regard and in general, inspiration and valuable insights have also been drawn from discussions with Takahiko Hattori, the Executive Supervisor for the United Nations Association's Test of English.

\section{AUTHOR INFORMATION}

Lawrence Karn, is Specially Assigned Lecturer of English at Otsuma Women's University, Japan and Adjunct Professor at Tokyo University of Foreign Studies, Japan and Jikei Medical University, Japan. He is a Ph.D. candidate at The Union Institute and University. Prof. Karn is the Vice-chairperson of the Advisory Committee for the United Nations Association’s Test of English. E-mail: lawrencekarn@ gmail.com

Takahiko Hattori, Ph.D. is Professor of Linguistics and Language Research at Otsuma Women's University, Japan and a Lecturer at Waseda University, Japan. He has published extensively, and made presentations both in Japan and North America related to English Language Education. He is the Executive Supervisor for the United Nations Association's Test of English. E-mail: hattori@ otsuma.ac.jp (Corresponding author)

\section{REFERENCES}

1. Amnesty International. Retrieved from http://www.amnesty.org/

2. $\quad$ Baier, A. The need for more than justice. In Held (ed.), Justice and care (pp. 47-58).

3. $\quad$ BBC World News. Should the rules of war be included in computer games? Retrieved from http://www.bbc.co.uk/news/technology-24318061

4. Bhabha, H. (2000). On cultural choice. In M. Garber, B. Hanssen, \& R. L. Walkowitz (eds.), The turn to ethics (Chapter 9). New York and London: Routledge.

5. Bread and Roses Credit Union history. Retrieved from http://www.connexions.org/CxLibrary/CX2153.htm

6. Co-op Housing Federation of Canada. Retrieved from http://www.chfcanada.coop/eng/pages 2007/home.asp

7. Experiments in compliance and attitude shift. Retrieved from http://hrsbstaff.ednet.ns.ca/devrob/Sociology $\% 2012 /$ pavlov.htm

8. Foucault. Retrieved from http://www.foucault.info/documents/foucault.technologiesofself.en.html

9. Gilligan, C. (1995). Moral orientation and moral development. In V. Held (ed.), Justice and care: Essential readings in feminist ethics (pp. 31-46). Boulder, CO: Westview Press.

10. Global Witness. Retrieved from http://en.wikipedia.org/wiki/Global_Witness

11. Greenpeace. Retrieved from http://www.greenpeace.org/international/en/

12. Griffin, J. H. (1962). Black like me. New York: Collins Publishing.

13. Hooks, B. (1993, Spring). A revolution of values: The promise of multi-cultural change. Journal of the Midwest Modern Language Association, 26(1).

14. Honneth, A. Integrity and disrespect: Principles of a conception of morality based on the theory of recognition. Retrieved from http://www.jstor.org/discover/10.2307/192001?uid=3738328

\&uid=2\&uid $=4 \&$ sid $=21102703385497$

15. Irigaray, L. (1995). The question of the other. Yale French Studies, 87, 7-19. 
16. Karma Co-op. Retrieved from http://www.karmacoop.org/

17. Mouffe, C. (2000). Which ethics for democracy? In M. Garber, B. Hanssen, \& R. L. Walkowitz, The Turn to Ethics. Ed. (Chapter 6). New York and London: Routledge.

18. Nussbaum, M. (1992, May). Human functioning and social justice: In defense of Aristotelian essentialism. Political Theory, 20(2), 202-246.

19. Rawls, J. (1999). A theory of justice. Harvard University Press.

20. Rawls, J. Justice as fairness: Political not metaphysical. Retrieved from http://www.jstor.org.proxy. myunion.edu/action/doBasicSearch?Query=Rawls+\%22Justice+as+Fairness\%22\&Search=Search\&gw=jtx \&prq=Rawls $+\% 22 \mathrm{Justice}+\mathrm{as}+$ Fairness $\% 22 \& \mathrm{hp}=25 \& \mathrm{acc}=$ off $\&$ aori $=$ off $\& \mathrm{wc}=$ on $\& \mathrm{fc}=$ off

21. Scott, J. (1991, Summer). The evidence of experience. Critical Inquiry, 17(4), 773-797.

22. Sivananda Ashram in the Bahamas. Retrieved from http://www.sivanandabahamas.org/

23. Stiglitz, J. E. (2013, October 13). Inequality is a choice. NY Times, Retrieved from http://opinionator.blogs.nytimes.com/2013/10/13/inequality-is-a-choice/?_r=0

24. Today's Guide to the United Nations (2007). Tokyo, Japan: Sanshusha Publishing.

25. Tronto, J. Women and caring: What can feminists learn about morality from caring?" In Held (ed.), Justice and Care (pp. 101-115).

26. United Nations observer missions Retrieved from http://en.wikipedia.org/wiki/List_of_United_Nations _peacekeeping_missions\#Current_deployment_.2816.29

27. United Nations test of English site. Retrieved from http://www.un.org/exam/lpe/welcome/main.asp

28. Windward Housing Co-op. Retrieved from http://windwardcoop.ca/ 
NOTES 